\title{
The tradeoff between liquidity and profitability: evidence from Indian manufacturing firms
}

\author{
Ahmed M. A. Hassan ${ }^{1}$, Catherine Nirmala ${ }^{2}$ \\ ${ }^{1}$ Research scholar, Department of commerce, Mangalore University, India \\ ${ }^{2}$ Research Guide, St Agnes Centre for PG Studies and Research, Mangalore

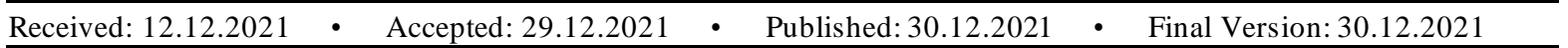

\begin{abstract}
The main aim of this research paper is to examine the trade-off between liquidity and profitability of Indian firms. The target population of the study is manufacturing firms. The study used convenience sampling for collecting the data. The study is based on secondary data for the period from 2008 to 2017 and 20 Indian manufacturing firms are selected for this purpose. Analysis of the data has been undertaken using SPSS software. Findings revealed that current liabilities ratio have a positive and significant impact on earnings per share and profit after tax. On the contrary, the current ratio and quick ratio have an insignificant impact on earnings per share, return on capital employed, return on assets and profit after tax. This study suggests that managers should incorporate liquidity into their evaluation decisions in order to boost the financial return of their businesses. The current study offers valuable insights into the success of Indian listed companies for administrators, analysts, regulators, investors, and other interested parties. There is insufficient research that has been conducted to examine the trade-off between liquidity and profitability. Furthermore, findings from this literature cannot be relied upon as they are outdated. Therefore, this study is going to provide updated evidence on the trade-off between liquidity and profitability of Indian manufacturing firms, an area that has largely remained unexplored.
\end{abstract}

Keywords: Firm profitability, liquidity ratios, manufacturing firms, India

\section{Introduction}

Liquidity refers to the availability of funds to meet working capital requirements and how quickly current assets can be converted into cash. It has a vital impact on the overall smooth functioning of a company. Understanding the concept of liquidity is crucial to both external and internal analysts is demonstrating a firm's potential to conduct its day-to-day operations (Al-homaidi et al., 2020; Elangkumaran and Karthika, 2013). The concept of liquidity is important for a business as it signify its capacity to fulfil its short-term financial obligations. The common indicators of liquidity are the ones that are used by companies that have the existing amounts of cash and marketable securities, which are those that exceed their long-term liabilities. The current ratio establishes the relationship between short-term assets and liabilities. In general, a high current ratio indicates that the firm's potential to fulfil short-term financial obligations is strong, while a low fast ratio indicates a low connection between a firm's current liabilities and its corresponding current assets. Liquid assets refer to those assets that can be converted into cash easily without incurring losses against their current market value. A low current ratio signify that a business is unable to meet its short-term financial commitments to creditors, service providers, and suppliers of products and services on time. (Owolabi et al., 2011, Alahdal et al., 2016). Wang (2002) discovered that proactive liquidity management improves a firm's financial efficiency and typically results in a firm's increased market value. Effective liquidity management downgrades and removes the risk of being unable to fulfil short-term financial obligations as they mature, while also preventing undue investment in these 
properties (Priya and Nimalathasan, 2013). Profitability information is important in operational and financial decision-making since it is useful for financial managers, shareholders, and investment analysts as a yardstick for dividend payments, a measure for assessing management efficiency, and a tool for evaluating decision making (Nassirzadeh and Rostami, 2010). Profitability and its corresponding concept of liquidity constitute critical issues that all commercial entities should continue to research and consider as one of their primary responsibilities. Nassirzadeh and Rostami (2010) consider liquidity to be very important, since low-and-zero-profits companies can serve the economy while companies without liquidity cannot serve the economy. Liquidity management and operational profitability are substantial areas for the growth and long-term survival of a company that require management to strike-a-balance between them (Priya and Nimalathasan, 2013). This paper aims to provide a review of literature on the relationship between liquidity and profitability of a firm using archival literature to explore the gap for future directions.

For any company, cash provides a protective shield and bulwark in its business operations. Thus, it serves as a backbone of working capital requirements and continuous business operations and its ultimate survival. (Boisjoly and Izzo, 2009; Gitman, 2009) noted that all companies must have an ample amount of funds that matches operational expenditure as dictated by the nature of the business operations to ensure continuous functioning (Boisjoly and Izzo, 2009; Gitman, 2009). The integrative model of managing cash largely rely on business operation cycle. Any deviations from this management stimulates a positive/negative impact on the effectiveness of working capital (Boisjoly and Izzo, 2009).

Ordinarily, firms hold cash to be in a position to pay for business operation expenditures such as compensations, taxation, dividends and essential operational needs. When a firm is able to synchronize its receipts and payments in its operations, it does not need to increase the current funds it holds as there is sufficient cash for its short-term needs. However, in practice, this is not always the case, as this synchronization is constantly violated. As a result, the firm resorts to raising the cash it holds as payments overtake receipts. One of the ways through which a firm or company can raise cash quickly is through investments in marketable securities, particularly those whose maturity matches with the terms of anticipated payments. This way is generally resorted to when the company has payments that are not perfectly matching with receipts. The motive of holding cash for this purpose is called the transaction motive.

The quick ratio and the current ratio are the most frequently used techniques or strategies for calculating liquidity and working capital requirements. The quick ratio is denoted by the difference between current assets and current liabilities, while the current ratio is equal to the difference between current assets and current liabilities. Additionally, these two ratios are used to assess corporate liquidity. Essentially, they determine if the business is able to meet its financial obligations through the sale of liquid assets (Farris et al., 2002). Nevertheless, several researchers including Emery (1984) and Kamath (1989) criticized these measures as they considered them to be static in nature. However, their opinions were largely ignored as several authors utilized them to evaluate corporate liquidity ("Bhunia et al., 2011; Bibi and Amjad, 2017; Elangkumaran and Karthika, 2013; Morgheim, 2015; Saleem \& Rehman, 2011; Zygmunt, 2013”). Therefore, this study seeks to evaluate the trade-off between liquidity and profitability of Indian manufacturing firms. The rest of the paper is structured as follow: section 2 presents a review of prior studies, section 3 demonstrates the research design, section 4 interprets and discusses the results and finally, section 5 gives a brief conclusion of the paper. 


\section{Literature review}

Numerous scholars have examined how liquidity affect profitability using conventional methods for determining liquidity of a firm, namely the liquidity ratio. Further, several researches indicate that there is a dearth of studies that address the issue of financial performance in India (e.g., Hashed \& Almaqtari, 2020; Almaqtari \& Hashed, et al., 2020; Farhan et al., 2019; Almaqtari \& Al-Hattami et al., 2020; Al Maqtari \& Ahdal et al., 2021; Hazaa, Almaqtari \& Al-Swidi, 2021; Almaqtari \& Al-Homaidi, et al., 2019; Al-Homaidi \& Tabash, et al., 2018; Al-Homaidi \& Almaqtari, et al., 2020; Al-Homaidi \& Tabash, et al., 2019). Numerous studies were consistent in their observations whilst others were contradictory. In this fashion, Elangkumaran and Karthika (2013), Khidmat (2014), Mushtaq et al. (2015), Owolabi et al. (2011) and Saleem and Rehman (2011) performed their research in a variety of sectors of varying sample sizes with the aim of determining the link between "liquidity and profitability". They all assessed liquidity using liquidity ratios and, profitability using a variety of different indicators. Owolabi et al. (2011) utilised the operational profit-to-turnover ratio; Khidmat (2014) used the return on assets and return on equity; and Elangkumaran and Karthika (2013) utilised the return on assets and earnings per share. Saleem and Rehman (2011), whereas on the other hand, the investigators applied three separate measures: "return on equity, return on assets, and return on investments"; in Mushtaq et al. (2015), meanwhile, the authors use return on assets. This investigation has shown to be quite beneficial in establishing a link between "liquidity and profitability". However, while Panigrahi (2013) and Krishnakumar (2010) researched India's software, cement, and steel industries using both "traditional liquidity indices and alternative profitability metrics such as return on investment, gross profit margin, return on assets, and earnings per share", Bhunia et al. (2011) and Panigrahi (2013) instead performed their research in these industries using both "the liquidity ratios metrics and alternative profitability metrics such as return on investment, gross profit margin, return on assets, and earnings per share". Findings were consistent with the notion that lower liquidity was correlated with lower profitability. While researching the data from Morgheim (2015), Owolabi et al. (2011), and Rehman et al. (2015), the previously cited researchers discovered that there is a negative relation between liquidity and profitability, as measured by traditional indices, according to three additional research projects done in the United States, Nigeria, and Saudi Arabia

Niresh (2012) sought to unravel the profitability-liquidity link. The research indicated a "mixed association between the independent and dependent variables" (positive and negative). The author observed a negative link between the current ratio and net profit and return on capital employed, but a positive association between the current ratio and return on equity. Additionally, the quick ratio correlates positively with net profit and return on capital employed, but negatively with return on equity. Hemalatha and Under (2005) sought to ascertain the liquidity and profitability of the chosen societies. Their study incorporated trend analysis, ratio analysis, variance analysis, and average and correlation coefficient calculations. The study concluded that "SWCSs failed to maintain an appropriate current and liquid ratios, owing to the fact that none of the SWCSs examined provided enough protection to creditors".

Using current liquidity indicators such as the detailed liquidity index, cash conversion period index, and net liquid balance index, researchers in "Kenya, Sweden, Nigeria, Turkey, Greece, Japan, Taiwan, and China" sought to establish the influence of liquidity on firm profitability. They arrived at diametrically opposed conclusions. Unlike previous researchers who relied on conventional indices to assess liquidity and its influence on profitability, "Nobanee et al. (2014), Tripathi \& Ahamed (2016), Uyar (2009), Wang (2002), Ware (2015), and Yazdanfar and hman (2014)" chose to measure liquidity using a modern index, namely the cash conversion period. All of this research used "descriptive statistics, correlation analysis, and regression models" to evaluate the connection between variables. Liquidity, they found, had an adverse influence on profitability as defined by "return on assets, return 
on equity, and return on investment". In the Greek food business, Lyroudi \& Lazaridis (2000) examined the link between liquidity as assessed by the cash conversion period and profitability as evaluated by "return on investment, return on equity, and net profit margin". They established a positive association between the cash conversion period and return on assets, return on equity, and net profit margin using regression and correlation analysis, as well as t-tests on two distinct samples. Duncan et al. (2015) objectively investigated and quantified the influence of cash management on deposit-taking institutions' financial performances. They developed a "self-administered standardised questionnaire for 92 respondents and gathered secondary data from the audited financial statements of the SACCOs and the regulator (SASRA)". The review of this study shows a strong positive relationship between cash management and financial performance. They recommended that SACCOs to accept deposits must have an appropriate cash management strategy in place to ensure optimum financial efficiency. By liquidity management (measured by the "cash flow management, credit policies, and cash conversion period of a firm"), Uyar (2009) argues that liquidity management has a significant impact on a firm's overall profitability.

Jihadi et al., (2021) tested the link between firm value and liquidity, operation, leverage, and profitability. The sampling methodology used was a random sample of 22 index companies that were publicly traded on the Indonesian Stock Exchange between 2014 and 2019. The study indicated that the liquidity, operation, leverage, and profitability ratios all contribute significantly to firm value. Priya and Nimalathasan (2013) and Zygmunt (2013) conducted studies in Poland and Sri Lanka, respectively, with a sample size of ten firms. They used correlation and regression analysis. Their research established a high association between business profitability and liquidity, as evaluated by contemporary and historical indexes. Nassirzadeh and Rostami (2010) and Sandhar and Janglani (2014), on the other hand, performed research in Saudi Arabia, Iran, and India, respectively. They used correlation and regression analysis to ascertain the trade-off between liquidity and profitability. Their study revealed that profitability and liquidity, as measured by both standard indexes, are adversely associated. There are only slight discrepancies in the research findings based on current liquidity indexes. According to Nassirzadeh and Rostami (2010) and Sandhar and Janglani (2014), although conventional liquidity indicators have a significant influence on profitability, current liquidity indices have a minor influence. Surprisingly, Bibi and Amjad (2017) examined the link between firm liquidity and profitability by examining the influence of all liquidity components on profitability on the Karachi Stock Exchange. They calculated liquidity using the cash difference in days and the current ratio. They established a substantial positive link between conventional profitability indicators and contemporary liquidity indices, but contemporary liquidity indices had a strong negative association with profitability.

Al-homaidi et al. (2019) studied the financial and operational liquidity factors that were important for all banks in India from 2008 to 2017. The findings indicate that "bank size, capital adequacy ratio, deposits ratio, operating efficiency ratio, and return on assets ratio all have a significant positive impact on liquidity, while assets quality ratio, asset management ratio, return on equity ratio, and net interest margin ratio all have a significant negative effect on liquidity". Farhan et al. (2019) investigated the effect of liquidity ratios on the financial results of Indian pharmaceutical companies. They found that pharmaceutical companies have strong financial positions. Al-homaidi et al. (2020) analysed the factors of liquidity for Indian publicly traded companies. The study indicated that "debt, return on assets, and firm age" are the primary internal determinants of liquidity in India. Additionally, the findings indicate that among the internal determinants, "firm size, leverage ratio, return on assets ratio, and firm age" all have a substantial positive association with firms' liquidity, except for leverage ratio and firm age which have a negative relationship with firms' liquidity. Sari and Sedana (2020) results revealed that net income statement data and financial soundness have a "positive and significant" impact on the capital structure. As for financial soundness, net income has a significant effect whilst it 
also serves to exacerbate capital structure, and deflate capital value. Dadepo and Afolabi (2020) examined the effect of liquidity management on the output of ten manufacturing firms from 2012 to 2016. The study discovered that the current ratio has a substantial negative effect on the profitability of the selected companies, while fast and cash ratios have a favourable but negligible effect on ROA. Putri and Wiksuana (2021) studied the effect of liquidity and profitability on firm value through the lens of dividend policy. The findings of this study indicate that liquidity has a significant negative impact on firm value, while profitability has a significant positive impact on firm value, and that the dividend policy is incapable of implying the effect of liquidity and profitability on firm value.

It is clear from the above discussion that there are a few studies that have analyzed the "trade-off between liquidity and profitability". Furthermore, these studies are not recent, a situation that renders their outcome outdated. Therefore, this study seeks to provide updated evidence on the trade-off between liquidity and profitability of Indian manufacturing firms, which is an area that has not been widely focused on by researchers.

\section{Research methodology}

The target population of the study is manufacturing firms. The study used convenience sampling for collecting the data. The reesrach is based on secondary data for the period from 2008 to 2017. 20 Indian manufacturing firms are selected for this purpose due to availability of data. The dependent variables are earnings per shares, return on assets, return on capital employed and profit after tax. The independent variables are cash to current liabilities, current ratio and quick ratio. In order to achieve the study objectives, descriptive statistics, correlation matrix and regression analysis are used and their results are interpreted further below. The following are the regression models which have been used in the analysis.

$$
\begin{aligned}
& (\mathrm{EPS})_{\mathrm{it}=} \alpha+\beta_{1}(\mathrm{CTCL})_{\mathrm{it}}+\beta_{2}(\mathrm{CR})_{\mathrm{it}}+\beta_{3}(\mathrm{QR})_{\mathrm{it}}+\varepsilon_{\mathrm{it}} \\
& (1) \\
& (\mathrm{ROCE})_{\mathrm{it}=} \alpha+\beta_{1}(\mathrm{CTCL})_{\mathrm{it}}+\beta_{2}(\mathrm{CR})_{\mathrm{it}}+\beta_{3}(\mathrm{QR})_{\mathrm{it}}+\varepsilon_{\mathrm{it}}(2) \\
& (\mathrm{ROA})_{\mathrm{it}=} \alpha+\beta_{1}(\mathrm{CTCL})_{\mathrm{it}}+\beta_{2}(\mathrm{CR})_{\mathrm{it}}+\beta_{3}(\mathrm{QR})_{\mathrm{it}}+\varepsilon_{\mathrm{it}} \\
& (\mathrm{PAT})_{\mathrm{it}=} \alpha+\beta_{1}(\mathrm{CTCL})_{\mathrm{it}}+\beta_{2}(\mathrm{CR})_{\mathrm{it}}+\beta_{3}(\mathrm{QR})_{\mathrm{it}}+\varepsilon_{\mathrm{it}}
\end{aligned}
$$

Where:

$($ EPS $)$ it $=$ Stands for earnings per share of firm I, at time $t$, defined by return on assets (ROA).

$(\mathrm{ROCE})$ it $=$ Return on capital employed of firm I, at time $\mathrm{t}$.

$(\mathrm{ROA})$ it $=$ Return on assets of firm $\mathrm{i}$ at time $\mathrm{t}$

$(\mathrm{PAT})_{\text {it }}=$ profit after tax of firm $i$ at time $t$.

$(\mathrm{CTCL})$ it = cash to current liabilities of firm i at time t.

$(\mathrm{CR})$ it $=$ current ratio of firm $\mathrm{i}$ at time $\mathrm{t}$.

$(\mathrm{QR})_{\text {it }}=$ quick ratio of firm $\mathrm{i}$ at time $\mathrm{t}$.

$(\alpha)=$ Common $y$-intercept.

$(\beta 1-\beta 3)=$ Coefficients of the explanatory indicators

$(\varepsilon)_{i t}=$ Stochastic error term of firm $i$ at time $t$. 
Table 1. Variable's description

\begin{tabular}{|c|c|c|c|c|}
\hline $\begin{array}{l}\text { Variable } \\
\text { Name }\end{array}$ & Symbol & Formula & $\begin{array}{l}\text { Expected } \\
\text { Signs }\end{array}$ & \\
\hline $\begin{array}{l}\text { Earnings Per } \\
\text { Share }\end{array}$ & EPS & $\begin{array}{l}\text { EPS }_{\text {it }} \\
=\frac{\text { Net profit }_{i t}}{\text { number of equity shareholders }}{ }_{i t}\end{array}$ & + & (Al-ahdal et a $1 ., 2018$ ) \\
\hline $\begin{array}{l}\text { Return on } \\
\text { Capital } \\
\text { Employed }\end{array}$ & ROCE & $\begin{array}{l}\text { ROCE }_{\text {it }} \\
=\frac{\text { EBIT }_{i t}}{\text { Total assets }- \text { current liabilities }}\end{array}$ & - & $\begin{array}{l}\text { (Al-ahdal \& Prusty, } \\
\text { 2020). }\end{array}$ \\
\hline $\begin{array}{l}\text { Return on } \\
\text { Assets }\end{array}$ & ROA & $\mathrm{ROA}_{\mathrm{it}}=\frac{\text { Net profit }_{\text {it }}}{\text { Total assets }_{\mathrm{it}}}$ & + & $\begin{array}{l}\text { (Prusty. \& Al-ahdal, } \\
2018 ; \quad \text { Al-Ahdal et } \\
\text { al.,2021) }\end{array}$ \\
\hline $\begin{array}{l}\text { Profit After } \\
\text { Tax }\end{array}$ & PAT & Net profit - tax & + & (Al-ahdal et a $1 ., 2018$ ) \\
\hline $\begin{array}{l}\text { Cash to } \\
\text { Current } \\
\text { Liabilities }\end{array}$ & CTCL & $\begin{array}{l}\text { CTCL }_{i t} \\
=\frac{\text { Cash \& Cash Equivalents }+ \text { Marketable }^{\text {Total Current Liabilities }}}{\text { it }}\end{array}$ & - & \\
\hline Current Ratio & $\mathrm{CR}$ & $\mathrm{CR}_{\mathrm{it}}=\frac{\text { current assets }_{\text {it }}}{\text { current liabilities }_{\text {it }}}$ & + & (Al-Ahdalet al.,2020) \\
\hline Quick Ratio & QR & 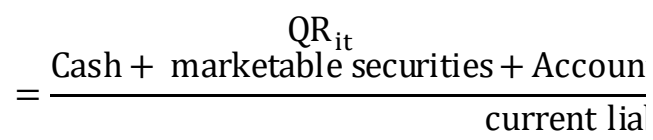 & + & \\
\hline
\end{tabular}

\section{Data analysis}

\subsection{Descriptive statistics}

Table (2) shows the central tendency for all variables used in the study. The central tendencies shown in table 2 are year-wise descriptive statistics except the last group which is based on the full study period. The results demonstrate the year-wise (from 2008 to 2017) descriptive statistics for the study variables, that is, earnings per share, return on capital employed, return on assets, profit after tax, cash ratio, current ratio and quick ratio.

Regarding the central tendency of all indicators in the article during the full period, table 2 shows that the mean value of earnings per share of the selected firms is 18.6930 with 41.8 standard deviation. The mean values of other profitability measures are 7.9529, 5.0362 and 460.3450 for return on capital employed, return on assets and profit after tax respectively, with 18.4, 15.1 and 2179.4 standard deviation respectively. Regarding the central tendency of independent variables, the mean values of "cash to current liabilities, current ratio and quick ratio" are .8836, 2.5347 and 2.0441 with 2.12955 , 3.81524 and 3.67874 standard deviation, respectively. 
Table 2. Descriptive statistics

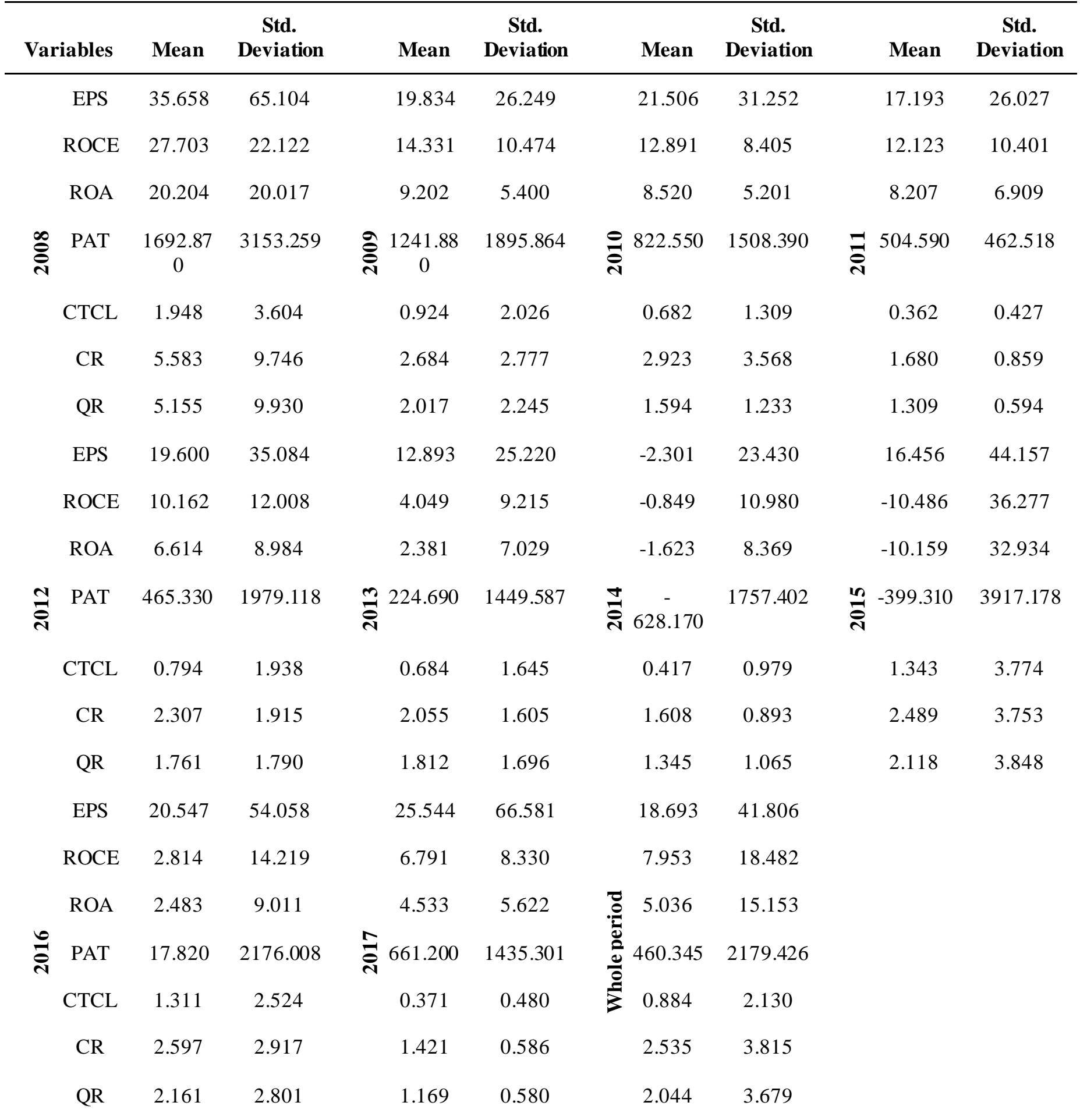

Notes: "Earnings per share (EPS), Return on capitalemployed (ROCE), Return on assets (ROA), Profit after tax (PAT), Cash ratio (CASHR), Current ratio (CR), Quick ratio (QR)".

\subsection{Correlation matric}

Correlation matrix is an econometric tool that examines the trend of relationship between the variables. It indicates the strength of the correlation between the study's factors. It also provides an indicator of multicollinearity absence and presence. Another critical aspect of the correlation matrix is revealing whether the multicollinearity issue exists among the variables, or not. Field (2009) suggested that "if any variable in the correlation matrix has a coefficient higher than 0.87 or 0.97 ", it reveals the presence 
of multicollinearity. The results in Table (3) reveal that there is no coefficient value greater or equal to 0.87 which confirm the absence of multicollinearity in the models. Pearson correlation is used to determine the trade-off between liquidity and profitability. The results in Table (3) indicate that the cash to current liabilities ratio, current ratio, and quick ratio all have a positive and statistically significant relationship with all profitability measures, including earnings per share, return on capital employed, return on assets, and profit after tax, for the entire sample period from 2008 to 2017.

Table 3. Correlation matrix

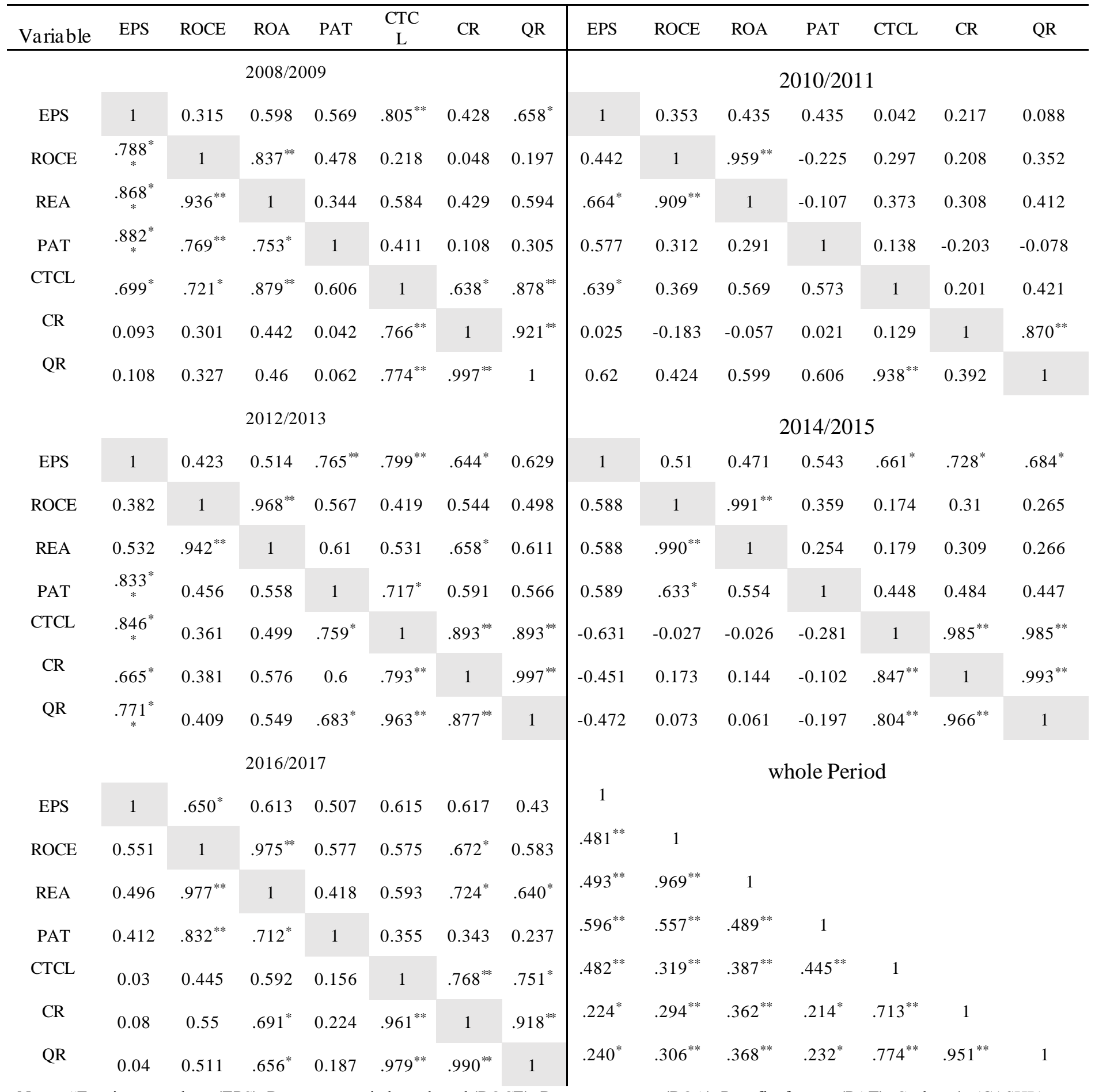

Notes: "Earnings per share (EPS), Return on capital employed (ROCE), Return on assets (ROA), Prpofit after tax (PAT), Cash ra tio (CASHR), Current ratio (CR), Quick ratio (QR)”. 


\subsection{Regression analysis}

The linear regression model is used to examine the impact of liquidity of the profitability of Indian manufacturing firms. The results in Table 4 shows the fitness of earnings per share model which is used for finding out the impact of liquidity on the earnings per share of Indian manufacturing firms. The table reveals that $\mathrm{R}$ square is 0.278 and the adjusted $\mathrm{R}$ square is 0.255 , which means that cash to current liabilities, current ratio and quick ratio explain 0.255 of the changes in earnings per share of Indian manufacturing firms and the remaining is explained by other variables which are not included in this study. These results mean that the regression model is a perfect fit at predicting the outcomes. The results in table 4 shows that the cash to current liabilities ratio has a positive and significant impact on earnings per share of Indian manufacturing firms. On the contrary, current ratio and quick ratio have an insignificant impact on the profitability of Indian manufacturing firms.

Regarding the impact of liquidity measures on return on capital employed of Indian financial firms, table 4 reveals that the return on capital employed model is a perfect fit. $\mathrm{R}$ square is 0.111 and the adjusted $\mathrm{R}$ square is 0.084 , which implies that the cash to current liabilities, current ratio and quick ratio explain 0.084 of changes in the return on capital employed of Indian manufacturing firms and the remaining is explained by other variables which are not included in this study. Further, the results in model 4 shows that the cash to current liabilities, current ratio and quick ratio have insignificant impact on return on capital employed of Indian manufacturing firms.

In case of the return on assets model, the results in Table 4 demonstrates the fitness of return on assets model which is used for finding out the impact of liquidity on the return on assets of Indian manufacturing firms. The table reveals that $\mathrm{R}$ square is 0.165 and the adjusted $\mathrm{R}$ square is 0.139 , which means that the cash to current liabilities, current ratio and quick ratio explain 00.139 of the changes in return on assets of Indian manufacturing firms and the remaining is explained by other variables which are not included in this study. Moreover, the results showed that the cash to current liabilities, current ratio positively and insignificantly impact return on assets of Indian manufacturing firms. In the same vein, the quick ratio negatively and insignificantly impact return on assets of Indian manufacturing firms.

Regarding the impact of liquidity measures on profit after tax of Indian financial firms, table 4 reveals that profit after tax model is a perfect fit. $\mathrm{R}$ square is 0.231 and the adjusted $\mathrm{R}$ square is 0.207 , which imply that the cash to current liabilities, current ratio and quick ratio explain 0.207 of changes in profit after tax of Indian manufacturing firms and the remaining is explained by other variables which are not included in this study. Furthermore, the results in model 4 shows that cash to current liabilities have a positive and significant impact on profit after tax of Indian manufacturing firms. On the other hand, current ratio and quick ratio have insignificant impact on profit after tax of Indian manufacturing firms. The findings of this study contradict those of Al-homaidi et al. (2020), Farhan et al. (2019) and Megaladevi (2018) who found out that there is a significant relationship between firm liquidity and financial performance of Indian listed firm. 
Table 4. Regression analysis

Earnings per shareis the dependent variable

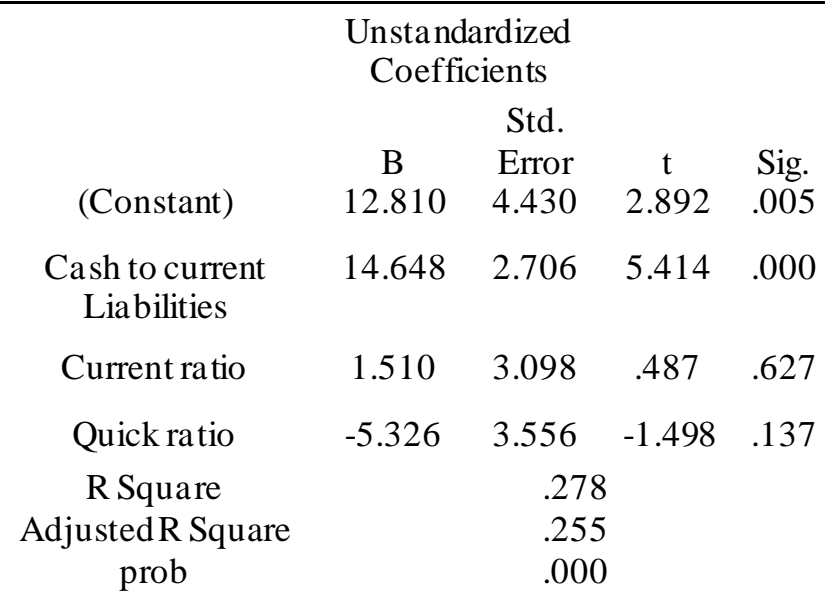

Return on assets is the dependent variable

\begin{tabular}{|c|c|c|c|c|c|c|c|c|c|}
\hline & \multicolumn{4}{|c|}{$\begin{array}{l}\text { Unstandardized } \\
\text { Coefficients }\end{array}$} & \multicolumn{5}{|c|}{$\begin{array}{l}\text { Unstandardized } \\
\text { Coefficients }\end{array}$} \\
\hline (Constant) & $\begin{array}{c}\mathrm{B} \\
1.603\end{array}$ & $\begin{array}{c}\text { Std. } \\
\text { Error } \\
1.727\end{array}$ & $\begin{array}{c}\mathrm{t} \\
.928\end{array}$ & $\begin{array}{l}\text { Sig. } \\
.356\end{array}$ & (Constant) & $\begin{array}{c}\text { B } \\
172.964\end{array}$ & $\begin{array}{c}\text { Std. } \\
\text { Error } \\
238.416\end{array}$ & $\begin{array}{c}\mathrm{t} \\
.725\end{array}$ & $\begin{array}{l}\text { Sig. } \\
.470\end{array}$ \\
\hline $\begin{array}{c}\text { Cash to current } \\
\text { Liabilities }\end{array}$ & 1.899 & 1.055 & 1.800 & .075 & $\begin{array}{c}\text { Cash to current } \\
\text { Liabilities }\end{array}$ & 682.987 & 145.612 & 4.690 & .000 \\
\hline Current ratio & .768 & 1.208 & .636 & .527 & Current ratio & 54.444 & 166.717 & .327 & .745 \\
\hline Quick ra tio & -.093 & 1.386 & -.067 & .947 & Quick ratio & -222.155 & 191.374 & -1.161 & .249 \\
\hline R Square & & .16 & & & R Square & & .231 & & \\
\hline $\begin{array}{c}\text { Adjusted R Square } \\
\text { prob }\end{array}$ & & $\begin{array}{l}.13 \\
.00 \\
\end{array}$ & & & $\begin{array}{c}\text { Adjusted R Square } \\
\text { prob }\end{array}$ & & $\begin{array}{l}.207 \\
.000 \\
\end{array}$ & & \\
\hline
\end{tabular}

\section{Conclusion}

The main aim of this research paper was to examine the trade of between liquidity and profitability of Indian manufacturing firms. The target population of the study is manufacturing firms. The study used convenience sampling for collecting the data. The study is based on secondary data for the period from 2008 to 2017. 20 Indian manufacturing firms are selected which their data are available for the full study period. SPSS software is used for analyzing the data. Cash to current liabilities ratio has a positive and significant impact on earnings per share and profit after tax and insignificant impact on return on capital employed and return on assets. Current ratio and quick ratio have insignificant impact on earnings per share, return on capital employed, return on assets and profit after tax.

Researchers believe that there are only few studies that are conducted to examine the trade of between liquidity and profitability. Further, these studies were conducted long back. Therefore, this study is going to provide updated evidence on the trade of between liquidity and profitability of Indian manufacturing firms which has been neglected by researchers. Thus, the current study provides an intriguing glimpse into the factors influencing listed firms' profitability in India. In India, only a few empirical studies have been conducted on this topic. Hence, this study attempts to fill a void in the body of literature on the profitability of firms in India. 


\section{References}

[1] Al-ahdal, W. M., \& Prusty, T. (2020). Does board structure index and ownership structure index impact on top listed Indian company's performance? International Journal ofBusiness Governance and Ethics, 14(4), 436-450.

[2] Alahdal, W. M., Alsa mhi, M. H., \& Prusty, T. (2016). The role of cost accounting system in the pricing decision-making in industrial companies of Taiz city, Yemen. International Academic Journal of Accounting and Financial Management, 3(7), 70-78.

[3] Al-ahdal, W. M., Prusty, T., Tabash, M. (2018). The impact of demonetization on Indian firms' performance: Does company's age make a difference? Investment Management \& Financial Innovations, 15(3), 71.http://dx.doi.org/10.21511/imfi.15(3).2018.06

[4] Al-Ahdal, W.M., Almaqtari, F.A., Tabash, M.I., Hashed, A.A. and Yahya, A.T. (2021), "Corporate governance practices and firm performance in emerging markets: empirical insights from India and Gulf countries", Vision: The Journal of Business Perspective, pp. 1-13, doi: 10.1177/09722629211025778.

[5] Al-Ahdal, W.M., Almaqtari, F.A., Zaid, D.A., Al-Homaidi, E.A. and Farhan, N.H. (2020), "Corporate characteristicsand leverage: evidence from Gulf countries", PSU Research Review, Vol. ahead-of-printNo. ahead-of-print. https://doi.org/10.1108/PRR-01-2020-0001

[6] Al-Homaidi, E. A., Almaqtari, F. A., Yahya, A. T., \& Khaled, A. S. (2020). Internal and extemal determinants of listed commercial banks' profitability in India: dynamic GMM approach. International Journal of Monetary Economics and Finance, 13(1),34-67.

[7] Al-homaidi, E. A., Tabash, M. I., Al-ahdal, W. M., Farhan, N. H. S., \& Khan, S.H. (2020). The Liquidity of Indian Firms: Empirical Evidence of 2154 Firms. Journal of Asian Finance, Economics and Business, 7(1),19-27.https://doi.org/10.13106/jafeb.2020.vol7.no1.19

[8] Al-homaidi, E. A., Tabash, M. I., Farhan, N.H., \& Almaqtari, F. A. (2019). The determinants of liquidity of Indian listed commercial banks: A panel da ta approach. Cogent Economics \& Finance, 7(1), 1-20. https://doi.org/10.1080/23322039.2019.1616521

[9] Al-Homaidi, E. A., Tabash, M. I., Farhan, N. H., \& Almaqtari, F. A. (2018). Bank-specific and macroeconomic determinants of profitability of Indian commercial banks: A panel data approach. Cogent Economics \& Finance, 6(1), 1548072.

[10] Al-Homaidi, E. A., Tabash, M.I., Farhan, N. H., \& Almaqtari, F.A. (2019). The determinants of liquidity of Indian listed commercialbanks: A panel da ta a pproach. Cogent Economics \& Finance, 7(1), 1616521.

[11] Almaqtari, F. A., Al-Ahdal, W.M., Mishra, N., \& Tabash, M.I. (2021). The effect of corporate govemance on compliance with Indian Accounting Standards: An empirical analysis of post IFRS convergence. Journal of Governance and Regulation, 10(4), 40-58.

[12] Almaqtari, F. A., Al-Hattami, H. M., Al-Nuzaili, K. M., \& Al-Bukhrani, M. A. (2020). Corporate governance in India: A systematic review and synthesis for future research. Cogent Business \& Management, 7(1), 1803579. https://doi.org/10.1080/23311975.2020.1803579

[13] Almaqtari, F. A., Al-Homaidi, E. A., Tabash, M. I., \& Farhan, N. H. (2019). The determinants of profitability of Indian commercial banks: A panel data approach. International Journal of Finance \& Economics, 24(1), 168-185.

[14] Almaqtari, F. A., Hashid, A., Farhan, N. H., Tabash, M. I., \& Al-ahdal, W. M. (2020). An empirical examination of the impact of country-level corporate governance on profitability of Indian banks. International Journal of Finance \& Economics, a head of print.

[15] Bhunia, A., Khan, I., \& MuKhuti, S. (2011). A study of managing liquidity. Journal of Management Research, 3(2). https://doi.org/10.5296/jmr.v3i2.574

[16] Bibi, N., \& Amjad, S. (2017). The rela tionship between liquidity and firms' profitability: A ca se study of Karachi Stock Exchange. Asian Journal of Finance \& Accounting. https://doi.org/10.5296/ajfa.v9i1.10600

[17] Boisjoly, R. P., \& Izzo, S. (2009). The cash flow implications of managing working capital and capital investment. Journal of Business and Economic Studies, 15(1), 98-109.

[18] Dadepo, A. O., \& Afolabi, O. F. (2020). Impact of Liquidity Management on Profitability of Selected Manufacturing Firms in Nigeria. European Journal of Business and Management, 12(27), 93-99. https://doi.org/10.7176/EJBM/12-27-11 
[19] Duncan, N. M., Njeru, A., Member, F., \& Tirimba, O. I. (2015). Effect of cash management on financial performance of Deposit Taking SACCOs in Mount Kenya Region. International Journal of Scientific and Research Publications, 5(2), 1-7.

[20] Elangkumaran, P., \& Karthika, T. (2013). An a nalysis of liquidity, profitability and risk: - A study of selected listed food, beverage and tobacco companies in Sri Lanka. 3rd International Conference, South Eastern University of SriLanka, (1), 1-7.

[21] Emery, G. W. (1984). Measuring short-term liquidity. Measuring Short-Term Liquidity, 4(4), 25-32.

[22] Farhan, N. H. S., Alhomidi, E., Almaqtari, F. A., \& Tabash, M. I. (2019). Does Corporate Govemance Moderate the Relationship between Liquidity Ratios and Financial Performance? Evidence from Indian Pharmaceutical Companies. Academic Journal of Interdisciplinary Studies, 8(3), 144-157. https://doi.org/10.36941/ajis-2019-0013

[23] Farris, I. I., Theodore, M., \& Hutchison, P. D. (2002). Cash-to-cash: the new supply chain management metric. International Journal of Physical Distribution and Logistics Management, 32(4), 288-298.

[24] Field, A. (2009). Discovering Statistics Using SPSS. International Journal of Psychophysiology, vol. 52. https://doi.org/10.1016/j.ijpsycho.2003.12.009

[25] Gitman, L. J. (2009). Principles of Managerial Finance (12th ed). Boston: MA: Pearson Prentice Hall.

[26] Hashed, A., \& Almaqtari, F. (2020). The im pact of corporate governance mechanisms a nd IFRS on earning management in Saudi Arabia. Accounting, 7(1), 207-224. https://doi.org/10.5267/j.ac.2020.9.015

[27] Hazaa, Y. M. H., Almaqtari, F. A., \& Al-Swidi, A. (2021). Factors Influencing Crisis Ma nagement: A systematic review and synthesis for future research. Cogent Business \& Management, 8(1), 1878979.

[28] Hemalatha, P., \& Under. (2005). A study of the financial structure, liquidity and Proceedings of Second International Fina nce Conference 2017 October 11th, 2017 Centre for Management Studies, Jamia Millia Isla mia, New Delhi-110025, India 763

[29] Jihadi, M., Vilantika, E., Hashemi, S. M., Arifin, Z., Bachtiar, Y., \& Sholichah, F. (2021). The Effect of Liquidity, Leverage, and Profitability on Firm Value: EmpiricalEvidence from Indonesia. The Joumal of Asian Finance, Economics and https://doi.org/10.13106/JAFEB.2021.VOL8.NO3.0423

[30] Ka math, R. (1989). How useful are common liquidity measures? Journal of Cash Management, 9(1), 2428.

[31] Khidmat, W. Bin. (2014). Impact of Liquidity \& Solvency on Profitability Chemical Sector of Pakistan. Economics Management Innovation, 6(3), 3-13.

[32] Krishnakumar. (2010). Liquidity and profitability of selected software companies in chennai. Published doctoral thesis. Iharathisasan University.

[33] Lyroudi, K., \& Lazaridis, Y.(2000). The ca sh conversion cycle and liquidity analysis of thefood industry in Greece.SSRN Electronic Journal.https://doi.org/10.2139/ssrn.236175

[34] Megaladevi, P. (2018). Determinants of liquidity and profitability of selected cement companies in India. International Journal of Commerce and Management Research, 4(5), 39-42.

[35] Morgheim, S. M. (2015). Assessing the relationship between financial slack and financial corporation performance. Northcentral University.

[36] Mushtaq, H., Chishti, A. F., Kanwal, S., \& Saeed,S. (2015). Trade off between liquidity and profitability. International Journal of Scientific ResearchandManagement, 3(5), 2823-2842. https://doi.org/28232842

[37] Na ssirzadeh, F., \& Rostami, A. (2010). Studying the relationship between liquidity indices ( tra ditional and modern ) and the profitability of Companies listed in Tehran Stock Exchange. Accounting and Auditing Review, (98511), 1-17.

[38] Niresh, J. A. (2012). Tra de-off between liquidity \& profitability: A study of selected manufacturing firms in Sri lanka. Journal of Arts, Science \& Commerce, 3(4), 34-40.

[39] Nobanee, H., Abdulla tif, M., \& AlHajjar, M. (2014). Cash conversion cycle and firm 's performance of Japanese firms. Asian Review of Accounting, 19(2), 147-156. https://doi.org/10.1108/13217341111181078

[40] Owolabi, S. A., Obiakor, R. T., \& Okwu, A. T. (2011). Investiga ting liquidity profitability relation ship in business organizations: A study of selected quoted Companies in Nigeria . British Journal of Economics, 
Finance and Management Sciences September 2011, Vol. 1 (2), 1(2), 11-29. https://doi.org/10.1017/CBO9781107415324.004

[41] Panigrahi, A. K. (2013). Liquidity management of Indian cement companies - A comparative study. IOSR Journal of Business and Management, 14(5), 49-61 .https://doi.org/10.9790/487X-1454961

[42] Priya, K., \& Nimalathasan, B. (2013). Liquidity management and profitability : A case study of listed manufacturing companies in Sri Lanka. Technological Exploration and Learning (IJTEL), 2(4), 161-165.

[43] Prusty, T. \& Ah-ahdal, W.M. (2018). Corporate governance and profitability: Evidence from Indian IT companies. Financial Markets Institutions and Risks, 2(3), 68-75.

[44] Putri, M. O. D., \& Wiksuana, I. G. B. (2021). Theeffect of liquidity and profitability on firm value mediated by dividend policy. American Journal of Humanities and Social Sciences Research, 5(1), 204-212.

[45] Rehman, M.Z., Khan, M. N., \& Khokhar, I. (2015). Investiga ting liquidity-profitability Farhan \& Yameen ISBN: 978-81-922331-4-7762

[46] Saleem, Q., \& Rehman, R. U. (2011). Impacts of liquidity ratios on profitability (Ca se of oil and gas companies of Pakistan). Interdisciplinary Journal of Research in Business, 1(July), 95-98.

[47] Sandhar, S. K., \& Janglani, S. (2014). A study on liquidity and profitability of selected Indian cement companies: A regression modeling approach. International Journal of Economics, Commerce and Management, II(7), 1-13. https://doi.org/234 0386

[48] Sari, I. A. G. D. M., \& Sedana, I. B. P. (2020). Profitability and Liquidity on Firm Value and Capital Structure as Intervening Variable. International Research Journal of Management, IT \& Social Sciences, 7(1), 116-127.

[49] Tripathi, N., \& Ahamed, N. (2016). Does optimizing the cash conversion cycle ameliorate firm's performance? Unraveling the relationship in the Indian corporate landscape, The Spread of Financial Sophistication through Emerging Markets WorldwidResearch in Finance, 32, 243 ?255 e, 32, 243-255. https://doi.org/10.1108/S0196-382120160000032010

[50] Uyar, A. (2009). The relationship of cash conversion cycle with firm size and profitability: An empirical investigation in Turkey. International Research Journal of Finance and Economics, 24(24), 187-193.

[51] Wang, Y.-J. (2002). Liquidity management, operating performance, and corporate value: evidence from Ja pan and Taiwan. Joumal of Multinational Financial Management 12, 12, 159-169.

[52] Ware,E. O. (2015). Liquidity management and its effect on profitability in a tough economy : (A case of companies listed on the Ghana Stock Exchange ). International Journal of Research in Business Studies and Management, 2(11),34-66.

[53] Yazdanfar, D., \& Öhman,P. (2014). The impact of cash conversion cycle on firm profitability An empirical study based on Swedish data. International Journal of Managerial Finance, 10(4), 442-452. https://doi.org/10.1108/IJMF-12-2013-0137

[54] Zygmunt, J. (2013). Does liquidity impact on profitability? A case of polish listed IT companies. Conference of Informatics and Management Sciences, 247-251. 